\title{
The sway of foreign direct investments on the performance of domestic firms ${ }^{1}$
}

\author{
Mico Apostolov ${ }^{2}$
}

\begin{abstract}
The purpose and research objective of this paper is the influence of foreign direct investments on the performance of domestic firms which is analyzed through a case study of Southeast Europe, and in particular of Macedonia. The conception of this analysis uses the methodology of the World Bank's Enterprise Surveys, which have been conducted on many countries using firmlevel data of representative sample of economy's private sectors. The data used in this article are analyzed with Tobit model, and as employed in this study it examines the impact of foreign ownership through set of variables. The main findings of the analysis demonstrate that foreign ownership has positively influenced the performance of domestic owned firms. As a consequence, an underlined conclusion of this research is that foreign direct investments influence various variables of a domestic economy and are major source of capital that can be used to power the overall economy foreword.
\end{abstract}

JEL Classifications: D22; F21; G30; L10; O10; P31

Keywords: FDI, performance, domestic firms, SEE, Macedonia

${ }^{1}$ Acknowledgements: This study is a part of the research project "Determination of the tourist events in the East region of the Republic of Macedonia" financed by University Goce Delcev Stip, Macedonia (Ref. No.2602-1291/5 form 07.11.2014).

${ }^{2}$ PhD, Assistant Professor, UGD, Krste Misirkov No.10-A P.O. Box 201, 2000 Stip, Macedonia. Scientific affiliation: international economics, microeconomics, business, management. Phone: Tel: $\quad+38932550$ 002. Fax: $+389 \quad 32 \quad 390$ 700. Personal website: http://scholar.ugd.edu.mk/micoapostolov. 